\title{
Importance of Small Forest Fragments in Agricultural Landscapes for Maintaining Orangutan Metapopulations
}

\section{OPEN ACCESS}

Edited by:

Edward T. A. Mitchard,

University of Edinburgh,

United Kingdom

Reviewed by:

Andrew John Marshall,

University of Michigan, United States

Cheryl Knott,

Boston University, United States

Badrul Azhar,

Putra Malaysia University, Malaysia

*Correspondence:

Marc Ancrenaz

marc.ancrenaz@gmail.com

Specialty section:

This article was submitted to

Tropical Forests,

a section of the journal

Frontiers in Forests and Global

Change

Received: 11 May 2020 Accepted: 11 January 2021 Published: 04 February 2021

Citation:

Ancrenaz M, Oram F, Nardiyono N Silmi $M$, Jopony MEM, Voigt $M$, Seaman DJI, Sherman J, Lackman I, Traeholt C, Wich SA, Santika T,

Struebig MJ and Meijaard E (2021) Importance of Small Forest Fragments

in Agricultural Landscapes for

Maintaining Orangutan

Metapopulations.

Front. For. Glob. Change 4:560944.

doi: 10.3389/ffgc.2021.560944

\author{
Marc Ancrenaz ${ }^{1,2,3 *}$, Felicity Oram ${ }^{3}$, Nardiyono Nardiyono ${ }^{4}$, Muhammad Silmi ${ }^{5}$, \\ Marcie E. M. Jopony ${ }^{6}$, Maria Voigt ${ }^{7,8}$, Dave J. I. Seaman ${ }^{7}$, Julie Sherman ${ }^{9}$, \\ Isabelle Lackman ${ }^{1}$, Carl Traeholt ${ }^{10}$, Serge A. Wich ${ }^{11,12}$, Truly Santika ${ }^{13}$, \\ Matthew J. Struebig ${ }^{7}$ and Erik Meijaard ${ }^{2,7,14}$
}

${ }^{1}$ HUTAN, Sandakan, Malaysia, ${ }^{2}$ Borneo Futures, Bandar Seri Begawan, Brunei, ${ }^{3}$ Pongo Alliance, Kuala Lumpur, Malaysia, ${ }^{4}$ PT Austindo Nusantara Jaya Tbk, Jakarta, Indonesia, ${ }^{5}$ United Plantations Berhad/PT Surya Sawit Sejati, Kumai Hulu, Indonesia, ${ }^{6}$ Wilmar International Ltd, Singapore, Singapore, ${ }^{7}$ Durrell Institute of Conservation and Ecology, University of Kent, Canterbury, United Kingdom, ${ }^{8}$ German Centre for Integrative Biodiversity Research (iDiv) Halle - Jena - Leipzig, Leipzig, Germany, ${ }^{9}$ Wildlife Impact, Portland, OR, United States, ${ }^{10}$ Copenhagen Zoo, Frederiksberg, Denmark, ${ }^{11}$ School of Biological and Environmental Sciences, Liverpool John Moores University, Liverpool, United Kingdom, ${ }^{12}$ Institute for Biodiversity and Ecosystem Dynamics, University of Amsterdam, Amsterdam, Netherlands, ${ }^{13}$ Natural Resources Institute, University of Greenwich, Chatham Maritime, Gillingham, United Kingdom, ${ }^{14}$ School of Biological Sciences, University of Queensland, St. Lucia, QLD, Australia

Historically, orangutans (Pongo spp.) lived in large contiguous areas of intact rainforest. Today, they are also found in highly modified and fragmented landscapes dominated by oil palm or industrial timber plantations; a situation that calls for new conservation approaches. Here we report signs of orangutan presence in more than 120 small forest fragments of $<500$ ha in size and isolated in extensive oil palm plantations across Borneo. We confirmed the long-term presence of adult resident females with dependent young in $42 \%$ of the fragments assessed by ground survey $(n=50)$, and the regular sightings of males traveling across the landscape. We argue that orangutans using and living in small isolated forest patches play an essential part in the metapopulation by maintaining gene flow among larger sub-populations distributed across multiple-use landscapes. In some cases, translocations may be necessary when the animals are in imminent danger of being killed and have no other refuge. However, the impacts of removing animals from spatially dispersed metapopulations could inadvertently decrease critical metapopulation functionality necessary for long-term viability. It is clear that orangutans need natural forest to survive. However, our findings show that forest fragments within agricultural landscapes can also complement conservation areas if they are well-distributed, properly connected and managed, and if orangutan killing is prevented. Efforts to better understand the dynamics and the functionality of an orangutan metapopulation in forest-farmland landscape mosaics characteristic of the Anthropocene are urgently needed to design more efficient conservation strategies for the species across its range.

Keywords: agricultural landscape, translocation, Borneo, oil palm, metapopulation, Pongo pygmaeus, forest fragment, great ape conservation 


\section{INTRODUCTION}

In wildlife conservation, the "Single Large or Several Small" (SLOSS) approach to conservation has been debated for decades [recent review in Fahrig (2020)]. Often, the prevailing policies and conservation strategies have favored large, connected "natural" areas, while considering fragments of natural habitat as of little or no value (IUCN, 1980; Sodhi et al., 2010). Indeed, small forest fragments are sensitive to microclimatic, anthropogenic and biological edge effects, support only a small proportion of the biodiversity of the original forest mostly consisting of invasive and generalist species that are of less conservation concern, and their value for conservation is often disregarded (Haddad et al., 2015; Pfeifer et al., 2017; Williamson et al., 2020). However, the importance of habitat heterogeneity and small habitat patches for biodiversity conservation and species dispersal is increasingly recognized (Azhar et al., 2015; Wintle et al., 2019; ArroyoRodriguez et al., 2020; Watling and Fang, 2020), especially for wide-ranging or volant species (Beca et al., 2017; Melo et al., 2017; Scriven et al., 2019).

In the past, orangutans (Pongo sp.) depended on vast tracts of natural forest. Today they persist and reproduce in forests logged for timber (Husson et al., 2009; Ancrenaz et al., 2010), in industrial timber plantations (Meijaard et al., 2010; Spehar and Rayadin, 2017) and in agricultural landscapes (CampbellSmith et al., 2011). They are also found in isolated patches of forest, albeit at lower densities than in more extensive natural forests (Ancrenaz et al., 2015; Seaman et al., 2019). In landscapes that have been extensively transformed by humans, orangutan survival is contingent on hunting and killing being minimized (Marshall et al., 2006; Husson et al., 2009; Spehar et al., 2018).

Here, we build on more than 20 years of orangutan research in the heavily disturbed and fragmented landscapes of the Kinabatangan floodplain (Sabah, Malaysian Borneo), and compile evidence of orangutans utilizing forest patches in oil palm-dominated landscapes across Borneo. We refine our current understanding of orangutan ecology in fragmented landscapes, identify knowledge gaps about the persistence of the species in these contexts, and provide some recommendations for conservation management of the species in heavily transformed habitats.

\section{ORANGUTANS SURVIVE AND APPEAR TO REPRODUCE IN THE MOSAIC LANDSCAPE OF KINABATANGAN}

The Lower Kinabatangan floodplain spans more than 500,000 ha and is largely dominated by oil palm agriculture, with fragmented and degraded forests covering $<15 \%$ of the region (Abram et al., 2014). Hutan, a local non-governmental group, has been studying wild orangutan ecology in this landscape since 1998 (Ancrenaz et al., 2004). For the past 22 years, we have regularly recorded orangutans in small forest patches, irrespective of their size or protection status. In 2008, we conducted helicopter nest surveys and confirmed the presence of orangutan nests in 32 small patches of forest isolated within oil palm estates, with an average size of 31 ha (range: 1 tree to 236 ha) [see detailed methodology in Ancrenaz et al. (2005) and Ancrenaz et al. (2015)]. We limited our ground and aerial investigation to patches $<500$ ha, which corresponds to the upper limit of a female range in most areas (Singleton et al., 2009). A forest fragment was considered isolated if the closest forest was $>500 \mathrm{~m}$ away, this gap being above the average daily distance traveled by orangutans in Kinabatangan (Oram, 2018). In 2012, we repeated the same helicopter survey and found that 15 forest fragments out of the 32 original patches still existed, the remainder having been cut down. We detected orangutan nests in 12 out of these 15 patches (Ancrenaz et al., 2015).

In addition to aerial surveys, our ground observations in Kinabatangan identified at least eight resident females who have survived for more than 10 years in very small ( $<50 \mathrm{ha}$ ) isolated forest fragments and have raised an infant successfully. We also established that some males traveled up to five kilometers between forest patches throughout the plantations (Ancrenaz et al., 2015). Orangutans build nests in palms, but they seem, more frequently, to nest in trees left within the monocultural cropland, perhaps because these trees are taller than nearby oil palm plants and offer vantage points and more safety.

Rather than being completely isolated, resident females appear to be part of a larger metapopulation, where subpopulations are linked by dispersal (Hastings and Harrison, 1994). In Kinabatangan, the presence of these orangutans established in forest patches, irrespective of their size or protection status, is inherently important to the long-term conservation of the species (Bruford et al., 2010).

\section{A SIMILAR SITUATION UNRAVELS IN OTHER OIL PALM LANDSCAPES IN BORNEO}

In 2008, additional helicopter surveys confirmed the presence of orangutan nests in isolated forest patches within the oil palm landscapes of eastern Sabah: Sandakan Bay (confirmed presence of nests in eight patches); Sugut floodplain (nests in 15 patches); Beluran (nests in seven patches), and Lower Segama (nests in 14 patches). Ten years later, using the same aerial methodology, we re-surveyed seven of the 15 patches in Sugut that had nests in 2008, and found nests in all seven patches. Although it is impossible to know whether the nests had been built by the same individuals between successive surveys or by transient animals, the nests' presence shows the use of the fragments by orangutans shortly before our surveys.

In 2019 and 2020, we conducted rapid ground assessments in nine oil palm estates located in southern Sabah, and in the West, Central and East provinces of Kalimantan (Indonesian Borneo). We also sent a questionnaire to the visited oil palm estates, and to three orangutan researchers working in these fragmented forest landscapes, about orangutan presence and potential conflicts in their estates, using a previously tested protocol (Meijaard et al., 2011; Ancrenaz et al., 2015).

The survey covered 70 patches of forest. Signs of orangutan presence (including pictures collected with camera traps, direct 
sightings of orangutans or nests) were confirmed in 50 of the 70 patches (i.e., $71 \%$ of the total) with an average patch size of 57 ha (range: 1-286 ha; SD $=72 \mathrm{ha}$ ). Presence of an adult female with young (from one to 5 years at the time of the surveys) was confirmed in 21 fragments (10-236 ha in size; mean 71; SD $=69$ ), and signs of adult females without young, or unflanged males (both types being extremely difficult to tell apart by direct sightings or from pictures) in 10 patches. Flanged males were present in four patches, and 15 patches had signs of orangutan nests without any indication of age and sex. Orangutans were absent from 20 patches at the time of surveys (0.5-369 ha in size; mean 81 ha; $S D=101 \mathrm{ha}$ ). Similar to our findings from Kinabatangan, estate managers and workers reported that crop damages in mature oil palms (i.e., above 5 years old) were considered non-significant, although several informants said that flower or fruit productivity might be impaired.

\section{ORANGUTAN TRANSLOCATION MAY BE DETRIMENTAL TO THE POPULATION}

Orangutan populations in a contiguous, but isolated, forest area containing fewer than 50 individuals are generally thought to be non-viable (Utami-Atmoko et al., 2019). Animals found in small forest patches are generally perceived as "doomed," because of insufficient food, the risk of getting killed by people, or the potential loss of remaining trees due to logging or fire (Sherman et al., 2020). Consequently, many wild orangutans observed in such habitat patches are pre-emptively translocated to large forest blocks presumed to be more suitable for their survival. In Indonesian Borneo between 621 and 1,845 wild orangutans were "rescued" from forest fragments in humanmodified landscapes between 2007 and 2017, and translocated to other forest areas (Sherman et al., 2020). The few data available on post-translocation monitoring indicate that translocated orangutans struggle to survive (Sherman et al., 2020).

Indeed, although orangutans are semi-solitary foragers, they live in diffuse communities of known and related individuals, in which females are resident and philopatric, and males disperse (Arora et al., 2012). Female orangutans are strongly tied to their natal areas, and the home ranges of maternal kin often overlap considerably (Van Noordwijk et al., 2012; Ashbury et al., 2020). These inherent features can pose extreme challenges for female orangutans when they are released into new forest areas (Lokuciejewski, 2018). In areas with existing resident females, competition for food will increase (Marzec et al., 2016). Resident adult flanged males aggressively defend an area with females in it, especially when females are sexually receptive (Spillmann et al., 2016), which could increase aggression and social stress when new males are released.

It is urgent to better document the fate of translocated individuals (Sherman et al., 2020) and to investigate the possible impact of removing individuals from forest patches on the orangutan metapopulation. Indeed, such a "harvest" could intensify the effects of fragmentation and jeopardize the longterm viability of the overall population. However, we also need to better document the chances of survival of orangutans within fragments and determine whether these small forest fragments serve only as temporary refuge to transient individuals or act like sinks to the overall population. Improved modeling and understanding of orangutan metapopulation dynamics in fragmented landscapes, and its counterfactual - i.e., what would have happened to orangutans had they not been removed from patches - is necessary to gain a better understanding of this new situation.

\section{DISCUSSION}

Orangutans are highly flexible and adaptable species that can maintain high population densities in production forests (Ancrenaz et al., 2010; Roth et al., 2020), and outside of strictlyprotected forests (Santika et al., 2017; Voigt et al., 2018). In these landscapes, orangutans can cope with canopy opening (Davies et al., 2017), disperse on the ground (Ancrenaz et al., 2014), and reproduce (Van Noordwijk et al., 2018). Our collation of reports from agricultural landscapes demonstrates substantial use of forest patches by orangutans in fragmented farmland, and gives some hints to better understand the functionality of a population within such a landscape.

In Borneo, agriculture development has resulted in significant deforestation across the orangutan range (Gaveau et al., 2016). We can hypothesize that some of the females who survived the initial deforestation took refuge in natural forest patches that were retained within their original range in this newly modified landscape. Indeed, female orangutans are reluctant to leave their natal areas, and this is also likely the case in forest patches (Arora et al., 2012; Van Noordwijk et al., 2012). Over the years, these females may have used as many forest patches within their former home-range as possible and likely remained safe by avoiding detection by people (Figure 1). But we can also suppose that some females originating from nearby source populations could recolonize the fragments after deforestation.

Orangutans need forest to survive and reproduce, and although they can feed on leaves, flowers and fruits of oil palms, they need a more diverse diet (Ancrenaz et al., 2015). Diversifying crops and promoting habitat heterogeneity and complexity will likely increase the orangutan's chances of survival in an agricultural context, as shown for other species (Azhar et al., 2014; Syafiq et al., 2016). Improving the overall forest connectivity within the agricultural landscape, and increasing the number, size and quality of forest fragments (enrichment planting for example), are necessary management strategies for increasing survival, but this remains still largely unstudied for orangutans. Another necessity is to ensure that potential negative conflicts between humans and orangutans are prevented or mitigated within these landscapes, and legal prohibitions on orangutan killing are properly enforced (Campbell-Smith et al., 2012).

Males are the most frequently observed sex in oil palm plantations, including numerous mentions of them walking on the ground, along rivers or streams and even on plantation roads. Orangutans use forest corridors to move across the landscape, as recorded by Seaman et al. (2019) and during our 


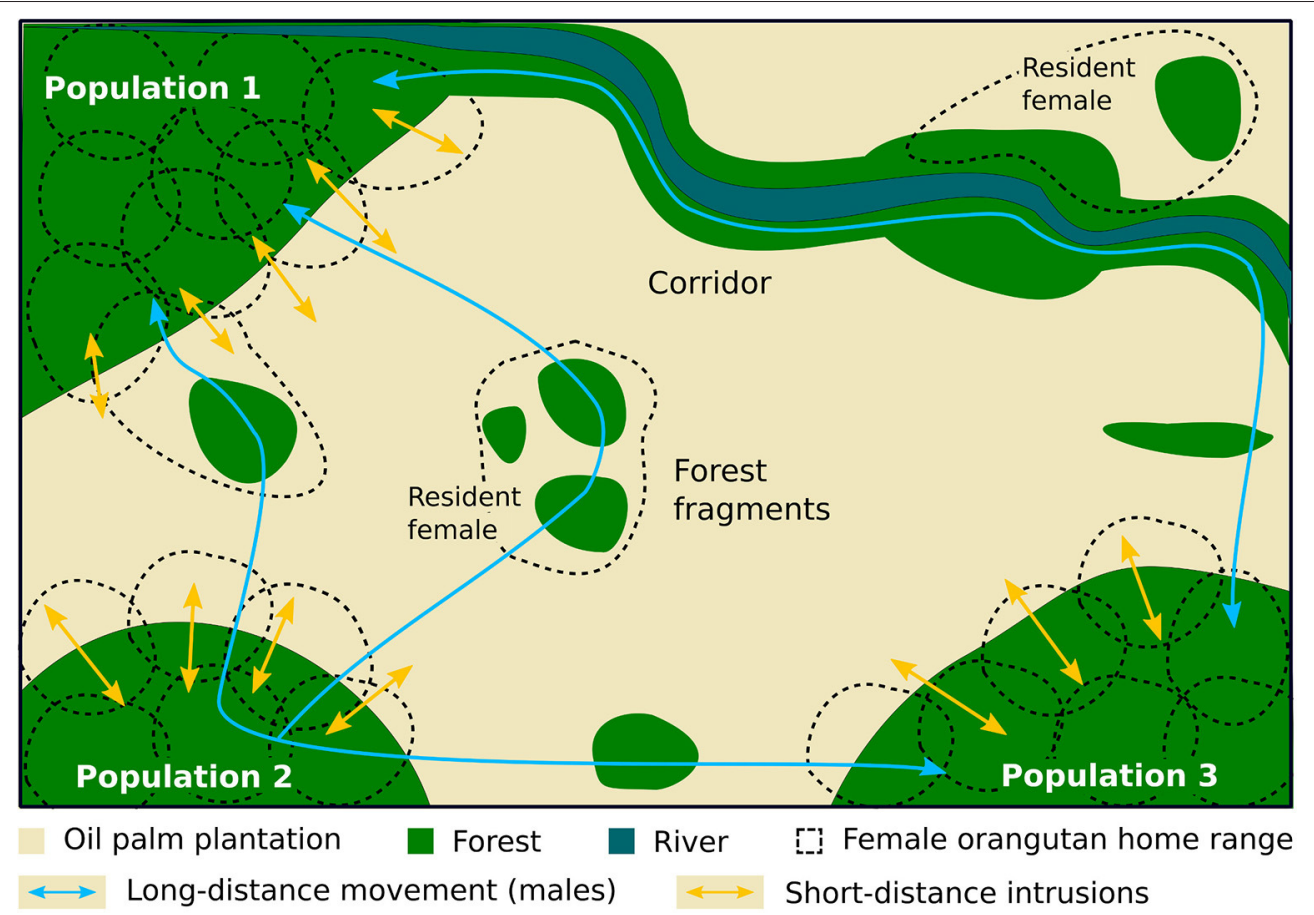

FIGURE 1 | Diagram showing the ranging pattern and ranging dynamic of wild orangutans in a fragmented landscape.

investigations. For example, one estate included in our analysis allowed natural forest regeneration under unmanaged oil palms in a $40 \mathrm{~m}$ wide corridor $1.2 \mathrm{~km}$ long, to link two isolated forest patches. Orangutan nests were observed in this corridor within 4 years following corridor establishment. These corridors are often set aside as high conservation value forests to meet sustainability certification criteria, either as riparian buffers or other linkages between forest patches. Retaining or creating forest corridors within oil palms will improve the permeability of the landscape for many species, in addition to orangutans (Gray et al., 2019; Scriven et al., 2019). The presence of resident adult females and their offspring in some of the isolated forest patches suggests that males are able to cross the human-modified landscape to search for receptive females and reproduce, but this hypothesis needs further investigation.

Many questions need to be addressed before we can consider a primarily agricultural landscape as viable long-term habitat for orangutans (Ancrenaz, 2015): What can orangutan eat and how can their dietary needs be met in small forest fragments in landscapes dominated by commercial monoculture, especially at times of low food availability (e.g., during prolonged droughts)?; What is the minimum size of forest patches and the maximum distance between patches to maintain an adequate geneflow? What are the risks associated with edge effects and the persistence of fragments as viable habitats (e.g., with respect to inbreeding, intrusion, etc.)?; What is the fate of young individuals that grow up in small isolated forest fragments: can adolescent females (which are the philopatric sex) disperse?; Is it possible to maintain a viable metapopulation in a fragmented landscape (or in other words: are the fragments acting as a sink or are they supporting a dynamic metapopulation)?; How is the gene flow maintained in a fragmented situation?; What are the risks of disease transmission between people, wild and domestic animals?; What type of management is needed to increase the chances of orangutan survival in a mosaic landscape?; How will the replanting of oil palm, typically every 20-25 years, affect orangutan populations utilizing the landscape?; Do the high levels of pesticides and fertilizer used in oil palm cultivation negatively affect orangutans?

Exclusively focusing our attention on larger groups of orangutans in contiguous forests (protected or not) will ultimately result in a disjointed distribution range where populations are no longer connected genetically. Here we hypothesize that long-term maintenance of habitat steppingstones within larger multifunctional landscapes could potentially retain some degree of connectivity between the larger forest areas occupied by orangutans and boost the chances of survival for the metapopulation as a whole. Conservation efforts for orangutans, and other endangered tropical species, must recognize the critical role habitat fragments may play to help stabilize and connect different landscapes at the broader metapopulation level.

This approach requires a change in perception about "rescuing and translocating" individuals. A recent analysis of wild-towild translocation in Kalimantan showed that at least $90 \%$ of the individuals captured were healthy and several of them had healthy infants (Sherman et al., 2020). Recognizing that there is a non-zero mortality risk during wild-to-wild translocations and reintroduction (Wilson and McMahon, 2006; Galdikas, 2018), 
we argue that, rather than emptying small forest patches of orangutans as a default operational practice, local authorities and conservation organizations ought to develop more proactive solutions, where forest patches are managed in a way that fosters positive coexistence between people and legally protected orangutans, as well as other wildlife.

An additional problem with translocations is that removing orangutans from a forest patch decreases its conservation value. Indeed, the presence of a fully protected species confers to a fragment a status of "High Conservation Value" with a specific set of management measures, including no-deforestation, hence reducing the likelihood of conversion (Carlson et al., 2018). The loss of the forest patch would then also mean the loss of all other wildlife that was not rescued, and of ecosystem services provided by the forest (Lucey et al., 2014; Wells et al., 2016).

Last we need to consider that at least 10,000 orangutans are surviving in multiple use landscapes in Borneo alone (Meijaard et al., 2017); rescuing all of them and finding suitable habitat to translocate them is unfeasible. Our preliminary investigation of orangutan survival in agricultural landscapes indicates that in situ management is a reasonable and in fact perhaps better conservation approach than translocating individuals which brings high risk to the animal at substantial financial cost.

Of course, there remain circumstances when the health of animals surviving in small fragments is compromised, e.g., food scarcity, forest destruction, physical harm or killing, and in such cases, translocations will still be needed when the alternative is a dead orangutan. Translocation is a part of the overall conservation toolbox, but this kind of intervention should be the exception rather than the norm.

For orangutans and other species to survive in mixed-use landscapes, farmers and companies must improve management and adopt biodiversity-friendly practices (Azhar et al., 2017). For example, forest fragments must be protected, monitored, managed, and enhanced if necessary. At a local scale, habitat heterogeneity could be improved by interspacing crops, planting trees, and promoting ground vegetation cover (Jambari et al., 2012). Non-hazardous chemicals (pesticides or herbicides, fertilizers) should be used rationally or phased out by promoting integration with livestock grazing and other environmentallyfriendly practices (Jambari et al., 2012; Azhar et al., 2017). Workers need to learn to not harass orangutans; conflicts need to be addressed peacefully; and risks of accidents (roads, feral dogs, culling) must be minimized (Azhar et al., 2013).

\section{REFERENCES}

Abram, N. K., Panteleimon, X., Tzanopoulos, J., MacMillan, D. C., Ancrenaz, M., Chung, R., et al. (2014). Synergies for improving forest conservation in oil palm dominated floodplain landscapes in Borneo. PLoS ONE 9:e95388. doi: 10.1371/journal.pone.0095388

Ancrenaz, M. (2015). The conservation management and conservation medicine of orang-utan in Sabah, Malaysia (PhD Dissertation). (Jr Nb 3772). Berlin: Freie Universität Berlin.

Ancrenaz, M., Ambu, L., Sunjoto, I., Ahmad, E., Manokaran, K., Meijaard, E., et al. (2010). Recent surveys in the forests of Ulu Segama Malua, Sabah, Malaysia,
In today's reality on Borneo and Sumatra, our observations indicate the need to consider orangutan metapopulation dynamics and gene flow in mixed-use landscapes. In other words, we hypothesize that most orangutan populations across fragmented landscapes could be viable if we maintain both existing larger protected areas and essential habitat fragments (even as small as a few ha), and minimize unnatural deaths or removal from the landscape. Therefore, the conservation unit to be managed should then not only be the animals in relatively well-protected larger forest areas, but the metapopulation that is ranging across the entire mixed protected-privately administered landscape as a whole. Eventually, the future of orangutans in the Anthropocene will primarily depend on the collaborative attitude of all land users and government working together to target a peaceful coexistence between people and orangutans outside and inside protected areas.

\section{DATA AVAILABILITY STATEMENT}

The raw data supporting the conclusions of this article will be made available by the authors, without undue reservation.

\section{AUTHOR CONTRIBUTIONS}

MA, FO, IL, and EM initially conceptualized this study. FO, NN, DS, MJ, MJS, MS, and CT contributed data. MV helped with data analysis and diagram design. MA, EM, FO, JS, CT, MJS, MV, TS, SW, and DS helped improve the manuscript. All authors contributed to the article and approved the submitted version.

\section{FUNDING}

In addition to all HUTAN supporters, we thank the United States Fish and Wildlife Service Great Ape Conservation Fund for financial support (grant number F17AP01081), the Arcus Foundation, New York, NY (grant number G-PGM-1610-1985), the IUCN Species Survival Commission Primate Specialist Group - Section on Great Apes (project grant number P02472), the Yayasan Sime Darby and the French Alliance for Preservation of Forests. The funders had no involvement in study design, in the collection, analysis and interpretation of data, or in the writing of the paper and the decision to submit the article for publication. show that orang-utans (P. p. morio) can be maintained in slightly logged forests. PLoS ONE 5:e11510. doi: 10.1371/journal.pone.0011510

Ancrenaz, M., Calaque, R., and Lackman-Ancrenaz I. (2004). Orangutan (Pongo pygmaeus) nesting behavior in disturbed forest (Sabah, Malaysia): implications for nest census. Int. J. Primatol. 25, 983-1000 doi: 10.1023/B:IJOP.0000043347.84757.9a

Ancrenaz, M., Gimenez, O., Ambu, L., Ancrenaz, K., Andau, P., Goossens, B., et al. (2005). Aerial surveys give new estimates for orangutans in Sabah, Malaysia. PLoS Biol. 3:e3. doi: 10.1371/journal.pbio.0030003

Ancrenaz, M., Oram, F., Ambu, L., Lackman, I., Ahmad, E., Elahan, H., et al. (2015). Of pongo, palms, and perceptions - a multidisciplinary 
assessment of orangutans in an oil palm context. Oryx 49, 465-472. doi: 10.1017/S0030605313001270

Ancrenaz, M., Sollmann, R., Meijaard, E., Hearn, A. J., Ross, J., Samejima, H., et al. (2014). Coming down the trees: is terrestrial activity in orangutans natural or disturbance-driven? Sci. Rep. 4:4024. doi: 10.1038/srep04024

Arora, N., Van Noordwijk, M. A., Ackermann, C., Willems, E. P., Nater, A., Greminger, M., et al. (2012). Parentage-based pedigree reconstruction reveals female matrilineal clusters and male-biased dispersal in nongregarious Asian great apes, the Bornean orang-utans (Pongo pygmaeus). Mol. Ecol. 21, 3352-3362. doi: 10.1111/j.1365-294X.2012.05608.x

Arroyo-Rodriguez, V., Fahrig, L., Tabarelli, M., Watling, J. I., Tischendorf, L., Benchimol, M., et al. (2020). Designing optimal human-modified landscapes for forest biodiversity conservation. Ecol. Lett. 23, 1404-1420. doi: $10.1111 /$ ele. 13535

Ashbury, A. M., Willems, E. P., Utami Atmoko, S. S., Saputra, F., Van Schaik, C. P., and Van Noordwijk, M. A. (2020). Home range establishment and the mechanisms of philopatry among female Bornean orangutans (Pongo pygmaeus wurmbii) at Tuanan. Behav. Ecol. Sociobiol. 74:42. doi: 10.1007/s00265-020-2818-1

Azhar, B., Lindenmayer, D. B., Wood, J., Fischer, J., and Zakaria, M. (2014). Ecological impacts of oil palm agriculture on forest mammals in plantation estates and smallholdings. Biodivers. Conserv. 23, 1175-1191. doi: 10.1007/s10531-014-0656-Z

Azhar, B., Lindermayer, D., Wood, J., Fisher, J., Manning, A., McElhinny, C., et al. (2013). Contribution of illegal hunting, culling of pest species, road accidents and feral dogs to biodiversity loss in established oil-palm landscapes. Wildlife Res. 40, 1-9. doi: 10.1071/WR12036

Azhar, B., Saadun, N., Prideaux, M., and Lindenmayer, D. B. (2017). The global palm oil sector must change to save biodiversity and improve food security in the tropics. J. Environ. Manage. 203, 457-466. doi: 10.1016/j.jenvman.2017.08.021

Azhar, B., Saadun, N., Puan, C. L., Kamarudin, N., Aziz, N., Nurhidayu, S., et al. (2015). Promoting landscape heterogeneity to improve the biodiversity benefits of certified palm oil production: evidence from Peninsular Malaysia. Glob. Ecol. Conserv. 3, 553-561. doi: 10.1016/j.gecco.2015.02.009

Beca, G., Vancine, M. H., Carvalho, C. S., Pedrosa, F., Alves, R. S. C., Buscariol, D., et al. (2017). High mammal species turnover in forest patches immersed in biofuel plantations. Biol. Conserv. 210, 352-359. doi: 10.1016/j.biocon.2017.02.033

Bruford, M. W., Ancrenaz, M., Chikhi, L., Lackman-Ancrenaz, I., Andau, M., Ambu, L., et al. (2010). Projecting genetic diversity and population viability for the fragmented orang-utan population in the Kinabatangan floodplain, Sabah, Malaysia. Endanger. Species Res. 12, 249-261. doi: 10.3354/esr00295

Campbell-Smith, G., Campbell-Smith, M., Singleton, I., and Linkie, M. (2011). Raiders of the lost bark: orangutan foraging strategies in a degraded landscape. PLoS ONE 6:e20962. doi: 10.1371/journal.pone.0020962

Campbell-Smith, G., Sembiring, R., and Linkie, M. (2012). Evaluating the effectiveness of human-orang-utan conflict mitigation strategies in Sumatra. J. Appl. Ecol. 49, 367-375. doi: 10.1111/j.1365-2664.2012.02109.x

Carlson, K. M., Heilmayr, R., Gibbs, H. K., Noojipady, P., Burns, D., Morton, D. C., et al. (2018). Effect of oil palm sustainability certification on deforestation and fire in Indonesia. Proc. Natl. Acad. Sci. U.S.A. 115, 121-126. doi: $10.1073 /$ pnas.1704728114

Davies, A. B., Ancrenaz, M., Oram, F., and Asner, G. P. (2017). Canopy structure drives orangutan habitat selection in disturbed Bornean forests. Proc. Natl. Acad. Sci. U.S.A. 114:8307. doi: 10.1073/pnas.1706780114

Fahrig, L. (2020). why do several small patches hold more species than few large patches? Glob. Ecol. Biogeogr. 29, 615-628, doi: 10.1111/geb.13059

Galdikas, B. M. F. (2018). OFI Translocated Orangutan Found Dead in Palm Oil Plantation.

Gaveau, D. L. A., Sheil, D., Husnayaen, Salim, M. A., Arjasakusuma, S., Ancrenaz, M., et al. (2016). Rapid conversions and avoided deforestation: examining four decades of industrial plantation expansion in Borneo. Nat. Sci. Rep. 6:32017. doi: $10.1038 /$ srep32017

Gray, R. E. J., Slade, E. M., Chung, A. Y. C., and Lewis, O. T. (2019). Movement of moths through riparian reserves within oil palm plantations. Front. Forest Glob. Change 2:68. doi: 10.3389/ffgc.2019.00068
Haddad, N. M., Brudvig, L. A., Clobert, J., Davies, K. F., Gonzales, A., Holt, R. D. et al. (2015). Habitat fragmentation and its lasting impact on Earth's ecosystems. Sci. Adv. 1:e1500052. doi: 10.1126/sciadv.1500052

Hastings, A., and Harrison, S. (1994). Metapopulation dynamics and genetics. Annu. Rev. Ecol. Syst. 25, 167-188. doi: 10.1146/annurev.es.25.110194.001123

Husson, S. J., Wich, S. A., Marshall, A. J., Dennis, R. A., Ancrenaz, M., Brassey, R., et al. (2009). "Orangutan distribution, density, abundance and impacts of disturbance," in Orangutans: Geographic Variation in Behavioral Ecology and Conservation, eds S. A. Wich, S. U. Atmoko, T. M. Setia, and C. P. Van Schaik (Oxford: Oxford University Press), 77-96. doi: 10.1093/acprof:oso/9780199213276.003.0006

IUCN (1980). World Conservation Strategy: Living Resource Conservation for Sustainable Development. Gland: International Union for Conservation of Nature and Natural Resources.

Jambari, A., Azhar, B., Ibrahim, N. L., Jamian, S., Hussin, A., Puan, C. L., et al. (2012). Avian biodiversity and conservation in Malaysian oil palm production areas. J. Oil Palm Res. 24, 1277-1286. Available online at: http://jopr.mpob.gov. my/wp-content/uploads/2013/09/joprv24april2012-Asrul1.pdf

Lokuciejewski, E. J. (2018). Post-release behaviour of reintroduced orangutans (Pongo pygmaeus wurmbii) in Bukit Baka Bukit Raya National Park and Bukit Batikap Conservation Forest, Central Kalimantan, Indonesia (MSc Thesis). Exeter: University of Exeter.

Lucey, J. M., Tawatao, N., Senior, M. J. M., Chey, V. K., Benedick, S. Hamer, K. C., et al. (2014). Tropical forest fragments contribute to species richness in adjacent oil palm plantations. Biol. Conserv. 169, 268-276. doi: 10.1016/j.biocon.2013.11.014

Marshall, A. J., Nardiyono, Engstrom, L. M., Pamungkas, B., Palapa, J., Meijaard, E., et al. (2006). The blowgun is mightier than the chainsaw in determining population density of Bornean orangutans (Pongo pygmaeus morio) in the forests of East Kalimantan. Biol. Conserv. 129, 566-578. doi: 10.1016/j.biocon.2005.11.025

Marzec, A. M., Kunz, J. A., Falkner, S., Atmoko, S. S. U., Alavi, S. E., Moldawer, A. M., et al. (2016). The dark side of the red ape: male-mediated lethal female competition in Bornean orangutans. Behav. Ecol. Sociobiol. 70, 459-466. doi: 10.1007/s00265-015-2053-3

Meijaard, E., Albar, G., Rayadin, Y., Nardiyono, Ancrenaz, M., and Spehar, S. (2010). Unexpected ecological resilience in Bornean orangutans and implications for pulp and paper plantation management. PLoS ONE 5:e12813. doi: 10.1371/journal.pone.0012813

Meijaard, E., Mengersen, K., Buchori, D., Nurcahyo, A., Ancrenaz, M., Wich, S. et al. (2011). Why don't we ask? A complementary method for assessing the status of great apes. PLoS ONE 6:e18008. doi: 10.1371/journal.pone.0018008

Meijaard, E., Morgans, C., Husnayaen, Abram, N. K., and Ancrenaz, M. (2017). An Impact Analysis of RSPO Certification on Borneo Forest Cover and Orangutan Populations. Brunei Darussalam: Borneo Futures.

Melo, G. L., Sponchiado, J., Cáceres, N. C., and Fahrig, L. (2017). Testing the habitat amount hypothesis for South American small mammals. Biol. Conserv. 209, 304-314. doi: 10.1016/j.biocon.2017.02.031

Oram, F. (2018). Abundance, feeding and behavioural ecology of orangutans (Pongo pygmaeus morio) in the fragmented forests of the Kinabatangan floodplain ( $\mathrm{PhD}$ Dissertation). Kota Kinabalu: University Malaysia Sabah (ITBC).

Pfeifer, M., Lefebvre, V., Peres, C., Banks-Leite, C., Wearn, O. R., Marsh, C. J., et al. (2017). Creation of forest edges has a global impact on forest vertebrates. Nature 551, 187-191. doi: 10.1038/nature24457

Roth, T. S., Rianti, P., Fredriksson, G. M., Wich, S. A., and Nowak, M. G. (2020). Grouping behavior of Sumatran orangutans (Pongo abelii) and Tapanuli orangutans (Pongo tapanuliensis) living in forest with low fruit abundance. Am. J. Primatol. 82:e23123. doi: 10.1002/ajp.23123

Santika, T., Ancrenaz, M., Wilson, K. A., Spehar, S., Abram, N., Banes, G. L., et al. (2017). First integrative trend analysis for a great ape species in Borneo. Sci. Rep. 7:4839. doi: 10.1038/s41598-017-04435-9

Scriven, S. A., Carlson, K. M., Hodgson, J. A., McClean, C. J., Heilmayr, R., Lucey, J. M., et al. (2019). Testing the benefits of conservation set-asides for improved connectivity in tropical agricultural landscapes. J. Appl. Ecol. 56, 2274-2285. doi: 10.1111/1365-2664.13472

Seaman, D. J. I., Bernard, H., Ancrenaz, M., Coomes, D., Swinfield, T., Milodowski, D. T., et al. (2019). Densities of Bornean orang-utans (Pongo pygmaeus morio) 
in heavily degraded forest and oil palm plantations in Sabah, Borneo. Am. J. Primatol. 81:e23030. doi: 10.1002/ajp.23030

Sherman, J., Ancrenaz, M., and Meijaard, E. (2020). Shifting apes: welfare and conservation outcomes of Bornean orangutan rescue and release in Kalimantan, Indonesia. J. Nat. Conserv. 55:125807. doi: 10.1016/j.jnc.2020.125807

Singleton, I., Knott, C. D., Morrogh-Bernard, H. C, Wich, S. A., and van Schaik, C. P. (2009). "Ranging behavior of orangutan females and social organization," in Orangutans: Geographic Variation in Behavioral Ecology and Conservation, eds S. A. Wich, S. U. Atmoko, T. M. Setia, and C. P. Van Schaik (Oxford: Oxford University Press), 205-215.

Sodhi, N. S., Koh, L. P., Clements, R., Wanger, T. C., Hill, J. K., Hamer, K. C., et al. (2010). Conserving Southeast Asian forest biodiversity in humanmodified landscapes. Biol. Conserv. 143, 2375-2384. doi: 10.1016/j.biocon.2009. 12.029

Spehar, S. N., and Rayadin, Y. (2017). Habitat use of Bornean orangutans (Pongo pygmaeus morio) in an industrial forestry plantation in East Kalimantan, Indonesia. Int. J. Primatol. 38, 358-384. doi: 10.1007/s10764-017-9959-8

Spehar, S. N., Sheil, D., Harrison, T., Louys, J., Ancrenaz, M., Marshall, A. J., et al. (2018). Orangutans venture out of the rainforest and into the anthropocene. Sci. Adv. 4:e1701422. doi: 10.1126/sciadv.17 01422

Spillmann, B., Willems, E. P., Van Noordwijk, M. A., Setia, T. M., and Van Schaik, C. P. (2016). Confrontational assessment in the roving male promiscuity mating system of the Bornean orangutan. Behav. Ecol. Sociobiol. 71:20. doi: 10.1007/s00265-016-2252-6

Syafiq, M., Atiqah, A. R. N., Ghazali, A., Asmah, S., Yahya, M. S., Aziz, N., et al. (2016). Responses of tropical fruit bats to monoculture and polyculture farming in oil palm smallholdings. Acta Oecol. 74, 11-18. doi: 10.1016/j.actao.2016.06.005

Utami-Atmoko, S., Traylor-Holzer, K., Rifqi, M. A., Siregar, P. G., Achmad, B., Priadjati, A., et al. (2019). Orangutan Population and Habitat Viability Assessment: Final Report. Apple Valley, MN: IUCN/SSC Conservation Breeding Specialist Group.

Van Noordwijk, M. A., Arora, N., Willems, E. P., Dunkel, L. P., Amda, R. N., Mardianah, N., et al. (2012). Female philopatry and its social benefits among Bornean orangutans. Behav. Ecol. Sociobiol. 66, 823-834. doi: 10.1007/s00265-012-1330-7

Van Noordwijk, M. A., Utami Atmoko, S. S., Knott, C. D., Kuze, N., MorroghBernard, H. C., Oram, F., et al. (2018). The slow ape: high infant survival and long interbirth intervals in wild orangutans. J. Hum. Evol. 125, 38-49. doi: 10.1016/j.jhevol.2018.09.004

Voigt, M., Wich, S. A., Ancrenaz, M., Meijaard, E., Abram, N., Banes, G. L., et al. (2018). Global demand for natural resources eliminated more than 100,000 Bornean orangutans. Curr. Biol. 28, 761-769.e765. doi: 10.1016/j.cub.2018.01.053

Watling, J., and Fang, R. (2020). Support for the habitat amount hypothesis from a global synthesis of species density studies. Ecol. Lett. 23, 674-681. doi: $10.1111 /$ ele.13471

Wells, J. A., Wilson, K. A., Abram, N. K., Nunn, M., Gaveau, D. L. A., Runting, R. K., et al. (2016). Rising floodwaters: mapping impacts and perceptions of flooding in Borneo. Environ. Res. Lett. 11:064016. doi: 10.1088/1748-9326/11/6/064016

Williamson, J., Slade, E. M., Luke, S. H., Swinfield, T., Chung, A. Y. C., Coomes, D. A., et al. (2020). Riparian buffers act as microclimatic refugia in oil palm landscapes. J. Appl. Ecol. 1-12. doi: 10.1111/1365-2664.13784

Wilson, R. P., and McMahon, C. R. (2006). Measuring devices on wild animals: what constitutes acceptable practice? Front. Ecol. Environ. 4, 147-154. doi: 10. 1890/1540-9295(2006)004[0147:MDOWAW]2.0.CO;2

Wintle, B. A., Kujala, H., Whitehead, A., Cameron, A., Veloz, S., Kukkala, A., et al. (2019). Global synthesis of conservation studies reveals the importance of small habitat patches for biodiversity. Proc. Natl. Acad. Sci. U.S.A. 116:909. doi: $10.1073 /$ pnas. 1813051115

Conflict of Interest: NN was employed by company PT Austindo Nusantara, MJ by Wilmar International Ltd, and MS by United Plantations Berhad/PT Surya Sawit Sejati.

The remaining authors declare that the research was conducted in the absence of any commercial or financial relationships that could be construed as a potential conflict of interest.

Copyright () 2021 Ancrenaz, Oram, Nardiyono, Silmi, Jopony, Voigt, Seaman, Sherman, Lackman, Traeholt, Wich, Santika, Struebig and Meijaard. This is an open-access article distributed under the terms of the Creative Commons Attribution License (CC BY). The use, distribution or reproduction in other forums is permitted, provided the original author $(s)$ and the copyright owner(s) are credited and that the original publication in this journal is cited, in accordance with accepted academic practice. No use, distribution or reproduction is permitted which does not comply with these terms. 